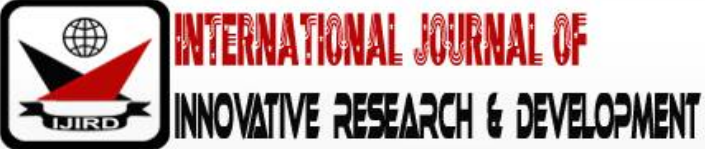

ISSN 2278 - 0211 (Online)

\section{Assessment of Irrigation Water Quality of Some Selected Fadama Farms in Jos North LGA of Plateau State of Nigeria}

\author{
Jauro,A.G. \\ Principal Research Officer, Department of Silviculture, \\ Forestry Research Institute of Nigeria, Nigeria \\ Nwafor ,E.0. \\ Principal Research Officer, Department of Agronomy \\ Forestry Research Institute of Nigeria, Nigeria \\ Sunday Oladipo \\ Lecturer, Department of Laboratory Science Technology \\ Federal College of Forestry, Jos Nigeria
}

\begin{abstract}
:
Water from irrigated Fadama Farms land in Jos North Local Government Area of Plateau State were assessed to ascertain their suitability for irrigation farming. The study area are Rafin Paa, Lamingo, Yalwa, Rikkos, Katako Bridge, Federal Government College, Jos, Student Village Hostel, Kunga, Tudun Wada, Naraguta Village, Maza village and Lambu Apata. All the waters were found to be neutral in reactions, except in Lamingo 2 that had $\mathrm{pH}$ of 5.8. Most of the $\mathrm{pH}$ range from 6.2-8.0 with mean (7.1). TDS values (in mgl"1) with mean 147, Ec, ' $\left(\mathrm{mscm}^{-1}\right)$ mean 143, SAR >3 and RSC mean >1. This suggests the irrigation waters are placed in $\mathrm{C}_{1} \mathrm{~S}_{1}$-low salinity water and low sodicity water categories. On the basis of combined TDS, Ec and SAR, the waters are rated fresh and safe for irrigation purposes for now.
\end{abstract}

Keywords: Fadama lands, irrigation water quality and salinity

\section{Introduction}

Irrigation water quality refers to its suitability for use. A good water quality has the potential to allow maximal yield under good soil and water management practices. However, with poor quality water, problems of salinized soil, impaired cropping and reduce yielded and be expected to develop unless special management practices are adopted to maintain or restore maximum soil production capability under a given set of conditions (Frenke, 1979).

Irrigation, applying water to assure sufficient soil moisture is necessary for good plant growth because it is used to argument rainfall (Thomas et al., 1996). The water quality used for irrigation is essential for the yield and qualities of crops, maintenance of soil productivity and protection of the environment for example, the physical and mechanical properties of the soil such as soil structure (stability of aggregates) and permeability, are very sensitive to the type of exchangeable ions present in irrigation water (Lennthtech, 2011).

Water used for irrigation and vary greatly in quality depending upon type and quality of dissolved salt. Salt are present in irrigation water in relatively small but significant amounts. They originate from dissolution or weathering of the rocks and soil, including dissolution of lime, gypsum and other slowly dissolved soil mineral. These salts are carried with water to where is sued in the case of irrigation, the salt are applied with the water and remain behind in soil as water evaporate or is used by the crop. (Ayers and Westcot, 1994). Salts in soil or water reduce water availability to the crop to such as extent that yield is affected (Ayers and Westcot, 1994) it is necessary for periodic assessment of irrigation water quality for improved productivity of the irrigation lands, it was against this background that this research work was undertaken with the following objectives.

- To ascertain current irrigation water quality and suitability in Jos North L.G.A.

- To evaluate salinity and sodicity status of soils in the study area.

\section{Materials and Methods}

This study was carried out in Rafin Paa, Lamingo, Yalwa, Rikkos, Katako, Bridge, Federal Government College, Jos, Student Village Hostel, Kunga, Tundu Wada, Naraguta Village, Maza Village and Lambu Apata of Jos North LGA of Plateau State. Jos is located in the central part of Nigeria between latitude $8^{0} 30^{\circ}$ and $10^{\circ} 30^{\prime} \mathrm{N}$ and longitude $8^{\circ} 20^{\prime}$ and $9^{\circ} 30^{\prime} \mathrm{E}$, with a surface area of about $9400 \mathrm{Km}^{2}$. It has meant annual temperature of about $22^{\circ} \mathrm{C}$ (Koppean, 1923). The plateau lies within 
Northern Guinean Savannah Vegetation Zone, which open woodland with tall grasses. Because of the wide variation in geological and topographic features, hence variation in soil types. Entisols, inceptisols, alfisols and ultisols are the major soils in the area (Olowolafe and Dung, 2000).

\section{Water Sampling}

A two (2) litre water sample collected from each sampling locations spots. The samples were respectively designated with the study sites.

\section{Methods}

The water samples were analysed for parameters in Table using the procedure described by Chopra and Kanwar (1991). Total Dissolved Solid (TDS) vas determined by the evaporation and drying method. The $\mathrm{pH}$ and Ec were read at $25^{\circ} \mathrm{C}$ on a pH and conductivity meters respectively. Calcium and magnesium were estimated by EDTA titration method while potassium and sodium by flame photometry, carbonate and bicarbonate were obtain by volumetric titration method. Sodium absorption ratio (SAR) was calculated using the formula:

$\mathrm{SAR}=\frac{\mathrm{Na}^{+}}{\sqrt{\frac{C a^{++}+M g^{++}}{2}}}$

Where, the ionic concentration is in milliequivalent per litre (steel and torrie, 19981).

\section{Result and Discussion}

\subsection{Total Dissolved Solid}

The concentration of dissolved solids in water in expressed as TDS. Table 1 shows that the concentration in the waters in the study areas were less than 100 mglı-1. Ranges from 0.92-3.80 mglı-1 with mean 147 indicate none degree of restriction on use.

They are related as "Fresh" according to the criteria set by Todd (1980).

Todd (1980) classified ground water on the basis of TDS (in mgl^-1) as fresh: 0-1000, Brackish: >1000-10,000, Saline: $>10,000-100,000$ and brinel $>100,000$. FAO (1985) gave limit for the TDS-based irrigation water categories as $<450-200$ and $>2000 \mathrm{mgl} \wedge-1$ with restrictions on its use as none, slight to moderate and severe respective.

\subsection{Current Quality Status}

Dewis and Fectes (1970), Richard (1954) states that the important characteristics that etermine the quantity of irrigation water are (1) total concentration of soluble salt, (2) relative proportion of sodium to calcium plus magnesium, (3) concentration of elements/ions that may accumulate to be phytototozic, and (4) under certain conditions, the concentration of bicarbonate plus carbonate as related to those of calcium plus magnesium. Results in Tables 1 - 2 relate to the above characteristics.

In light of FAO (1985) criteria water from all the farms with Ec ( $\left.\mu \mathrm{s} \mathrm{cm}^{\wedge}-1\right)$ ranges 0.20-3.80, man 143 can be used for irrigation purposes without any restrictions.

\subsection{Salinity Hazards}

Based on Ec in (mscm $\left.{ }^{\wedge}-1\right)$ which is a measure of salinity hazards, U.S. sainity laboratory staff (1954) classified irrigation water in four classes as $\mathrm{Cl}$ - low salinity water: Ec $<250$, C2-medium salinity water: Ec $>2250$. However, these limits were considered to be low. Therefore, FAO (1985) put forward three new Ec ( $\left.\mu \mathrm{s} \mathrm{cm} \mathrm{c}^{\wedge}-1\right)$ categories as $>700,700-300$ and $>3000$ with restriction on the use for irrigation as none, slight to moderate and severe, respectively.

\subsection{Sodicity Hazards}

According to U.S. salinity laboratory staff (1954), the sodium adsorption ratio (SAR) - based classes are S1 low sodium water; SAR <10, S2 medium sodium SAR 10-18, S3 high sodium water, 18-26, and S4 very sodium water: SAR >26. The FAO (1985) proposed SAR ranges as $<3,3-9$ and $>9$ with restrictions on use for surface irrigation as none, slightly to moderate and severe, respectively. Since all the water tested SAR >3 (Table 1), they belong S1 - low sodium water category which placed irrigation waters as suitable for irrigation purposes without any restrictions with respect to sodicity hazards.

\section{Conclusion}

On combined TDS: $<400$, Ec: 150, RSC: $<4$ and SAR: $<3$ basis, the water in the study areas can be rated as fresh and be classified as $\mathrm{C}_{1} \mathrm{~S}_{2}$ - low salinity, low sodicity water category. Suitable for irrigation purpose. 


\begin{tabular}{|c|c|c|c|c|c|}
\hline S/ N & Description of Sampling spot & pH & Ec & TDS & SAR \\
\hline 1 & Rafin Paa 1 & 7.7 & 3.80 & 0.87 & 2.17 \\
\hline 2 & Rafin Paa 2 & 6.7 & 0.42 & 2.86 & 0.78 \\
\hline 3 & Lamingo 1 & 7.4 & 1.40 & 0.82 & 0.13 \\
\hline 4 & Lamingo 2 & 5.8 & 0.20 & 0.35 & 0.50 \\
\hline 5 & Yelwa Mistabo 1 & 8.0 & 3.20 & 1.86 & 1.13 \\
\hline 6 & Yelwa Mistabo 2 & 7.2 & 0.30 & 1.88 & 0.41 \\
\hline 7 & Rikkos 1 & 7.0 & 3.20 & 1.21 & 0.23 \\
\hline 8 & Rikkos 2 & 7.4 & 0.40 & 2.50 & 0.52 \\
\hline 9 & Katako 1 & 7.2 & 0.80 & 1.75 & 0.26 \\
\hline 10 & Katako 2 & 6.2 & 0.32 & 2.00 & 0.39 \\
\hline 11 & Federal Govt. College Jos 1 & 7.4 & 2.88 & 0.99 & 0.61 \\
\hline 12 & Federal Govt. College Jos 2 & 6.8 & 0.14 & 1.20 & 0.28 \\
\hline 13 & Student Village Hostel 1 & 8.2 & 2.80 & 1.11 & 0.29 \\
\hline 14 & Student Village Hostel 2 & 7.1 & 0.84 & 1.70 & 0.63 \\
\hline 15 & Konga 1 & 7.5 & 1.80 & 0.75 & 0.10 \\
\hline 16 & Konga 2 & 8.3 & 2.20 & 0.92 & 0.37 \\
\hline 17 & Tundun Wada & 7.4 & 2.00 & 1.36 & 2.17 \\
\hline 18 & Tundun Wada & 6.8 & 0.80 & 0.80 & 0.39 \\
\hline 19 & Maza Village & 7.1 & 0.16 & 0.92 & 0.45 \\
\hline 20 & Maza Village & 6.6 & 1.08 & 3.80 & 0.44 \\
\hline & Mean & 7.15 & 1.35 & 1.50 & .45 \\
\hline & Std. Deviation & .587 & 1.309 & .889 & .686 \\
\hline & CV & .35 & 1.7 & .78 & .47 \\
\hline
\end{tabular}

Table 1: Ph, Ec and TDS in Water of Jos North Irrigation Fadama Farms Sample

\begin{tabular}{|c|c|c|c|c|c|}
\hline S/ N & Description of Sampling spot & $\mathbf{N a}^{+}$ & $\mathbf{K}^{+}$ & $\mathbf{C a}^{++}$ & $\mathbf{M a}^{++}$ \\
\hline 1 & Rafin Paa 1 & 0.63 & 1.32 & 2.38 & 1.14 \\
\hline 2 & Rafin Paa 2 & 0.75 & 2.13 & 0.98 & 0.86 \\
\hline 3 & Lamingo 1 & 0.54 & 1.33 & 1.41 & 0.91 \\
\hline 4 & Lamingo 2 & 0.63 & 0.98 & 1.86 & 1.25 \\
\hline 5 & Yelwa Mistabo 1 & 0.43 & 1.25 & 1.89 & 0.85 \\
\hline 6 & Yelwa Mistabo 2 & 0.56 & 2.56 & 2.43 & 1.25 \\
\hline 7 & Rikkos 1 & 0.66 & 1.10 & 1.25 & 0.79 \\
\hline 8 & Rikkos 2 & 0.61 & 0.84 & 2.54 & 0.25 \\
\hline 9 & Katako 1 & 0.52 & 0.53 & 0.26 & 0.73 \\
\hline 10 & Katako 2 & 0.44 & 0.69 & 1.67 & 0.93 \\
\hline 11 & Federal Govt. College Jos 1 & 0.34 & 0.72 & 0.93 & 0.56 \\
\hline 12 & Federal Govt. College Jos 2 & 0.34 & 1.11 & 1.25 & 1.63 \\
\hline 13 & Student Village Hostel 1 & 0.84 & 1.25 & 1.43 & 0.66 \\
\hline 14 & Student Village Hostel 2 & 0.54 & 0.75 & 0.98 & 0.51 \\
\hline 15 & Konga 1 & 0.38 & 1.43 & 2.83 & 0.33 \\
\hline 16 & Konga 2 & 1.09 & 0.42 & 1.41 & 0.74 \\
\hline 17 & Tundun Wada 1 & 0.73 & 1.26 & 1.26 & 0.62 \\
\hline 18 & Tundun Wada 2 & 0.43 & 0.63 & 1.34 & 1.08 \\
\hline 19 & Maza Village 1 & 0.54 & 1.64 & 1.96 & 0.67 \\
\hline 20 & Maza Village 2 & 0.57 & 1.17 & 1.57 & 0.84 \\
\hline & Mean & .70 & 1.15 & 1.50 & .95 \\
\hline & Std. Deviation & .470 & .587 & .761 & .394 \\
\hline & CV & .22 & .35 & .58 & .16 \\
\hline
\end{tabular}

Table 2: Exchangeable Bases in Water of Jos North Irrigation Fadama Farm Plateau State 


\begin{tabular}{|c|c|c|c|c|c|}
\hline S/ N & Description of Sampling spot & $\mathbf{C}_{\mathbf{0}^{-}}$ & $\mathbf{H C O}^{-}$ & $\mathbf{S O}^{-}$ & $\mathbf{R S C}$ \\
\hline 1 & Rafin Paa 1 & 0.00 & 0.90 & & 2.62 \\
\hline 2 & Rafin Paa 2 & 0.00 & 1.20 & & 0.64 \\
\hline 3 & Lamingo 1 & 0.00 & 0.13 & & 6.19 \\
\hline 4 & Lamingo 2 & 0.00 & 0.80 & & 2.31 \\
\hline 5 & Yelwa Mistabo 1 & 0.00 & 0.10 & & 2.65 \\
\hline 6 & Yelwa Mistabo 2 & 0.00 & 1.00 & & -2.68 \\
\hline 7 & Rikkos 1 & 0.00 & 0.23 & & 1.81 \\
\hline 8 & Rikkos 2 & 0.00 & 1.00 & & -268 \\
\hline 9 & Katako 1 & 0.00 & 0.23 & & 1.81 \\
\hline 10 & Katako 2 & 0.00 & 1.00 & & -1.79 \\
\hline 11 & Federal Govt. College Jos 1 & 0.00 & 0.15 & & 0.83 \\
\hline 12 & Federal Govt. College Jos 2 & 0.00 & 0.90 & & 1.34 \\
\hline 13 & Student Village Hostel 1 & 0.00 & 0.19 & & -1.98 \\
\hline 14 & Student Village Hostel 2 & 0.00 & 0.80 & & 1.90 \\
\hline 15 & Konga 1 & 0.00 & 0.30 & & -0.69 \\
\hline 16 & Konga 2 & 0.00 & 0.50 & & 3.05 \\
\hline 17 & Tundun Wada & 0.00 & 0.70 & & 1.75 \\
\hline 18 & Tundun Wada & 0.00 & 1.00 & & -1.38 \\
\hline 19 & Maza Village & 0.00 & 1.60 & & -1.35 \\
\hline 20 & Maza Village & 0.00 & 0.80 & & -2.31 \\
\hline & Mena & .00 & .65 & & .67 \\
\hline & Std. Deviation & .000 & .587 & & 2.388 \\
\hline & CV & .000 & .35 & & .57 \\
\hline
\end{tabular}

Table 3: Anions Concentration in Water of Jos North LGA Irrigated, Fadama Farm of Plateau State

\section{References}

i. Ayers, R.S. and Westcot, D.W. (1994). Water quality for agricultural irrigation and drainage Paper, No. 29, Rev. 1. FAO Rome, Italy.

ii. Chopra, S.L. and Kanwar, J.S. (1991). Analytical agricultural chemistry Fouth Edition. Kelyani Publishers, New Delhi, India.

iii. FAO, (1985). Guidelines land on Evaluation for Irrigation Soil. Bul. No. 55, FAO, Rome, Italy.

iv. Frenke, H. (1979). Assessment of water quality for irrigation Acta Horticulture (ISHS), 89, 29-30.

v. Koppean, W.S. (1923). Die Klimate der Erede: Walter der Gruster. Berling, Pp. 1-44 in Nigeria Journal of Botany, 20(2), 373-381.

vi. Lenntech, B.V. (2011). Irrigation water quality rotterdamseweg 402. M262. Hh Deifi, the Netherlands.

vii. London, J.R. (1991). Booker tropical soil manual. Longman Scientific and Technical, Essex, England.

viii. Olowolafe, E.A. and Dung, I.E. (2000). Soil derived from biotite granites on Jos-Plateau, Nigeria. Their nutrient status and management for sustainable agriculture. Resources, Conservation and Research, 29, 231-244.

ix. Richard, L.A. (1954). Diagnosis and improvement of Saline and Alkali soil. Hand book No. 60, U.S.D.A. Washington D.C. U.S.A.

x. Steel, R.C. and Torrie, J.H. (1981). Principles and procedures of Statistics Macmillan, New York, U.S.A.

xi. Thomas, F.S., Bruce, S. and Frenzen, B. (1996). Soil, Water and plant characteristics important of irrigation EB-66.

xii. Todd, D.K. (1980). Ground water hydrology, second edition John Weley \& Sons. New York, U.S.A. 